\title{
CHARACTERIZATION AND KINETICS OF PLASMA-PASTE-BORIDED AISI 316 STEEL
}

\author{
KARAKTERIZACIJA IN KINETIKA PLAZMA BORIRANJA S \\ PASTO JEKLA AISI 316
}

\author{
Redouane Chegroune ${ }^{1}$, Mourad Keddam ${ }^{1}$, Zahra Nait Abdellah ${ }^{2}$, Sukru Ulker ${ }^{3}$, \\ Sukru Taktak ${ }^{3}$, Ibrahim Gunes ${ }^{3}$ \\ ${ }^{1}$ Laboratoire de Technologie des Matériaux, Faculté G.M. et G.P., USTHB, B.P. 32, 16111 El-Alia, Bab-Ezzouar, Algiers, Algeria \\ 2Département de Chimie, Faculté des sciences Université Mouloud Mammeri, Tizi-Ouzou, 15000, Algeria \\ ${ }^{3}$ Department of Metallurgical and Materials Engineering, Faculty of Technology, Afyon Kocatepe University, 03200, Afyonkarahisar, Turkey \\ chegroune_redouane@yahoo.fr, rchegroune@usthb.dz
}

Prejem rokopisa - received: 2015-01-31; sprejem za objavo - accepted for publication: 2015-03-11

doi: $10.17222 / \mathrm{mit} .2015 .031$

In this work, AISI 316 steel was plasma-paste borided in a gas mixture of $70 \% \mathrm{H}_{2}-30 \%$ Ar using a mixture of $30 \% \mathrm{SiC}+$ $70 \% \mathrm{~B}_{2} \mathrm{O}_{3}$ as a boron source. The samples were treated at temperatures of $(700,750$ and 800$){ }^{\circ} \mathrm{C}$ for $(3,5$ and 7$) \mathrm{h}$. The morphology of the formed boride layers was examined by light microscope and scanning electron microscope coupled to an EDS analyser. The borides present in the boride layer were identified by means of XRD analysis. The boron-activation energy for the AISI 316 steel was found to be equal to $250.8 \mathrm{~kJ} \mathrm{~mol}^{-1}$. This value for the energy was compared to the literature data. A regression model based on a full factorial design was used to estimate the boride layers' thicknesses as a function of the boriding parameters: time and temperature. A comparison was made between the values of the boride layers' thicknesses estimated from the regression model with those given by an empirical relation. In addition, an iso-thickness diagram was plotted to predict the boride-layer thickness as a function of the processing parameters. This iso-thickness diagram can serve as a simple tool to select the optimum values for the boride layers' thicknesses for a practical utilisation in industry for this kind of steel.

Keywords: plasma paste boriding, kinetics, borides, transition zone, activation energy, regression model

$\mathrm{V}$ tem delu je bilo jeklo AISI 316 borirano s plazmo v mešanici plinov $70 \% \mathrm{H}_{2}-30 \% \mathrm{Ar}$, z uporabo mešanice $(30 \% \mathrm{SiC}+$ $\left.70 \% \mathrm{~B}_{2} \mathrm{O}_{3}\right)$, kot vir bora. Vzorci so bili obdelani pri treh temperaturah $(700,750$ in 800$){ }^{\circ} \mathrm{C}$ v trajanju (3, 5 in 7) h. Morfologija nastale boridne plasti je bila preiskovana s svetlobnim mikroskopom in z vrstičnim elektronskim mikroskopom, opremljenim z EDS analizatorjem. Boridi v borirani plasti so bili identificirani $\mathrm{z}$ rentgensko analizo. Aktivacijska energija bora $\mathrm{v}$ jeklu AISI 316 je bila $250,8 \mathrm{~kJ} \mathrm{~mol}^{-1}$. Ta vrednost je bila primerjana s podatki iz literature. Za določanje debeline borirane plasti $\mathrm{v}$ odvisnosti od parametrov boriranja (čas in temperatura), je bil uporabljen regresijski model, ki temelji na upoštevanju faktorjev. Izvršena je bila primerjava debeline borirane plasti, določene z regresijskim modelom in primerjava s tisto, ki je bila določena empirično. Za napovedovanje debeline borirane plasti je bil postavljen diagram enake debeline $\mathrm{v}$ odvisnosti od procesnih parametrov. Diagram enake debeline je uporaben kot enostavno orodje pri izbiri optimalne debeline borirane plasti, za praktično uporabo v industriji za to vrsto jekla.

Ključne besede: plazma boriranje s pasto, kinetika, boridi, prehodno področje, aktivacijska energija, regresijski model

\section{INTRODUCTION}

The boriding process is widely used in industry because of its broad application range. ${ }^{1}$ This thermochemical treatment is generally performed in the range $700{ }^{\circ} \mathrm{C}$ to $1050{ }^{\circ} \mathrm{C}$. The boriding process results in a metallic boride layer of about $20 \mu \mathrm{m}-300 \mu \mathrm{m}$ thickness. The boriding treatment can be carried out in solid, liquid, gaseous or plasma media. ${ }^{2-5}$ Due to their relatively small size and very mobile nature, boron atoms can diffuse into the surface material to form hard borides. In the case of ferrous materials, the boriding treatment leads to the formation of either a single layer $\left(\mathrm{Fe}_{2} \mathrm{~B}\right)$ or a double-layer $\left(\mathrm{FeB}+\mathrm{Fe}_{2} \mathrm{~B}\right)$ with a definite composition. The boridelayer thickness is determined by the temperature and treatment time. The characteristics of this boride layer depend on the physical state of the boron source used, the boriding temperature, the treatment time, and the chemical composition of the material to be borided. ${ }^{6-9}$
In order to lower the boriding temperature and the process time, ion-implantation boriding ${ }^{10}$, and plasmaassisted boriding ${ }^{11}$ have been employed. Although the plasma boriding process has an advantage over the powder- or paste-boriding process, the use of expensive gases such as $\mathrm{B}_{2} \mathrm{H}_{6}$ and $\mathrm{BCl}_{3}$ for the plasma-boriding process poses a major problem related to their toxicity. To overcome this problem, an alternative was recently proposed by using the plasma paste boriding (PPB) process. This recently developed method uses inert gases such as hydrogen, argon and nitrogen, making it very advantageous. ${ }^{5}$

The objective of this work was to investigate the boriding kinetics of AISI 316 steel by plasma paste boriding. The boron-activation energy for the AISI 316 steel was also estimated basing on our experimental results. 


\section{MATERIALS AND METHODS}

In this study the AISI 316 austenitic steel used for the plasma paste boriding has the following chemical composition given in Table 1.

Table 1: Chemical composition of AISI 316 stainless steel (in mass fractions, $w / \%$ )

Tabela 1: Kemijska sestava nerjavnega jekla AISI 316 (v masnih deležih, $w / \%$ )

\begin{tabular}{|c|c|c|c|c|c|c|c|c|}
\hline $\mathrm{C}$ & $\mathrm{Cr}$ & $\mathrm{Mo}$ & $\mathrm{Mn}$ & $\mathrm{Si}$ & $\mathrm{Ni}$ & $\mathrm{P}$ & $\mathrm{S}$ & $\mathrm{Fe}$ \\
\hline 0.08 & 16 & 2 & 2 & 0.75 & 10 & 0.045 & 0.03 & balance \\
\hline
\end{tabular}

The samples had a cylindrical shape and were $20 \mathrm{~mm}$ in diameter and $5 \mathrm{~mm}$ in height. The surfaces of the AISI 316 steel were mechanically polished in sequence with (600, 800, 1200 and 2400) grit wet SiC emery paper, followed by fine polishing with an alumina slurry. The samples were cleaned in alcohol before the plasma paste boriding. In this study, a mixture of powder $(30 \% \mathrm{SiC}+$ $70 \% \mathrm{~B}_{2} \mathrm{O}_{3}$ ) constituting a boron source was applied, where silicon carbide ( $\mathrm{SiC}$ ) was used as a catalyst for the $\mathrm{B}_{2} \mathrm{O}_{3}$ paste. The plasma paste boriding was carried out in a dc plasma system, which is described in detail in the work by Gunes et al. ${ }^{5}$ Argon gas is important for the plasma system. It is used to change the plasma parameters such as the electron temperature and the electron density, which influence the production of active species by inelastic collisions, plasma reactions and plasma surface interactions. During the plasma paste boriding, $\mathrm{H}_{2}$ gas plays an important role. Borax reacts with active hydrogen $\left(\mathrm{H}^{+}\right)$in a glow discharge. Atomic boron was produced through the decomposition of the boron hydride $\left(\mathrm{B}_{\mathrm{x}} \mathrm{H}_{\mathrm{y}}\right)$ from the paste, and this atomic boron became the active boron, $\mathrm{B}^{+1}$, within the molten borax or in the glow discharge. Finally, this active boron $\mathrm{B}^{+1}$ diffused and reacted with the Fe to form the boride layer. The samples of AISI 316 austenitic steel were plasma paste borided at $(700,750$ and 800$){ }^{\circ} \mathrm{C}$ for $(3,5$ and 7$) \mathrm{h}$

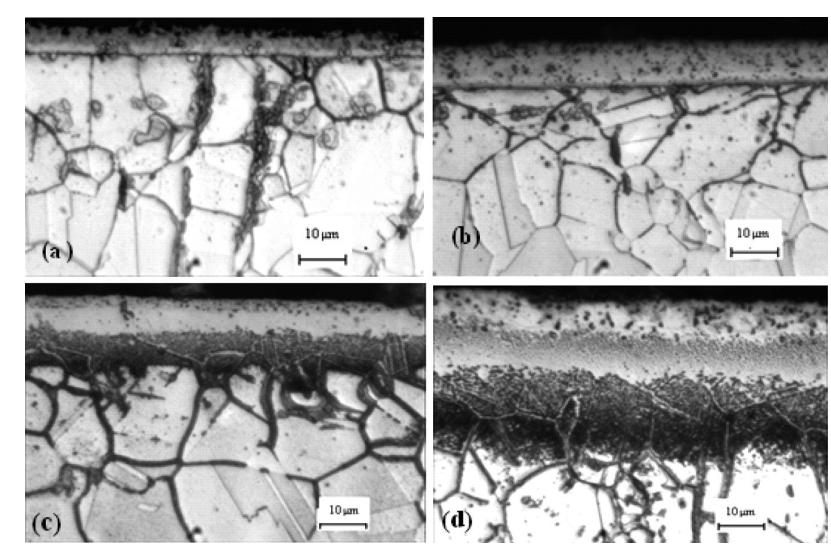

Figure 1: Light micrographs showing the microstructures of boride layers formed on the AISI 316 steel for different boriding parameters: a) $700{ }^{\circ} \mathrm{C}$ for $7 \mathrm{~h}$, b) $750{ }^{\circ} \mathrm{C}$ for $7 \mathrm{~h}$, c) $800{ }^{\circ} \mathrm{C}$ for $3 \mathrm{~h}$, d) $800{ }^{\circ} \mathrm{C}$ for $5 \mathrm{~h}$ Slika 1: Svetlobni posnetki mikrostruktur boriranih plasti na AISI 316 jeklu, pri različnih parametrih boriranja: a) $700{ }^{\circ} \mathrm{C}, 7 \mathrm{~h}$, b) $750{ }^{\circ} \mathrm{C}, 7 \mathrm{~h}$, c) $800{ }^{\circ} \mathrm{C}, 3 \mathrm{~h}$, d) $800{ }^{\circ} \mathrm{C}, 5 \mathrm{~h}$ in a gas mixture of $70 \% \mathrm{H}_{2}-30 \%$ Ar under a constant pressure of 10 mbar. The temperature of the samples was measured by means of a chromel-alumel thermocouple, placed at the bottom of the treated samples. After the plasma paste boriding process, each borided sample was cleaned in an ultrasonic bath with alcohol. The treated samples were chemically etched using a chemical solution consisting of $20 \mathrm{~mL}$ glycerine, $10 \mathrm{~mL} \mathrm{HNO}_{3}$ and 30 $\mathrm{mL} \mathrm{HCl}$. The morphology of boride layers was observed using a light microscope (Olympus Vanox AHMTS) and a LEO 1430 VP model Scanning Electron Microscope (SEM). The values of boride layers' thicknesses were taken as averages of at least 10 measurements.

The presence of different borides formed in the boride layer was confirmed by means of an XRD analysis. This analysis was carried out using a Philips X-ray diffractometer with $\mathrm{Cu}-K_{\alpha}$ radiation $\left(\lambda_{\mathrm{Cu}}=0.154 \mathrm{~nm}\right)$. The distribution of alloying elements was analysed by energy-dispersive X-ray spectroscopy (EDS) from the surface towards the substrate.

EDS line analyses were performed to determine which element accumulated across the boride layer and the transition zone.

\section{RESULTS AND DISCUSSION}

\subsection{Observation of the morphology of the boride layers}

Figure 1 shows the etched cross-sections of boride layers formed on the surfaces of AISI 316 steel at different temperatures and for various treatment times. It reveals the formation of a bilayer configuration composed of $\mathrm{FeB}$ and $\mathrm{Fe}_{2} \mathrm{~B}$. A transition zone exists in all the optical micrographs due to the accumulation of undissolved elements beneath the boride layer. The morphology of the boride-layer/transition-zone interface exhibited a flat diffusion front due to the effects of the main alloying elements such as $\mathrm{Cr}$, Mo and Ni. This fact can be explained by the reduction of the active boron flux in the diffusion zone by the presence of these elements. It is clear that the thicknesses of the boride layer and the transition zone are affected by the process parameters (time and temperature). For instance, the boride layer's thickness reached a value of $10.4 \mu \mathrm{m}$ at $750{ }^{\circ} \mathrm{C}$ for $7 \mathrm{~h}$, while its corresponding value was $5.11 \mu \mathrm{m}$ at a temperature of $700{ }^{\circ} \mathrm{C}$ during $7 \mathrm{~h}$ of treatment. Furthermore, some precipitates (i.e., chromium carbides) were also observed along the austenitic grain boundaries revealed by the chemical etchant composed of $20 \mathrm{~mL}$ glycerine, $10 \mathrm{~mL} \mathrm{HNO}_{3}$ and $30 \mathrm{~mL} \mathrm{HCl}$.

Figure 2 gives the cross-sectional views of microstructures of borided AISI 316 steel. The $\mathrm{FeB}$ and $\mathrm{Fe}_{2} \mathrm{~B}$ layers are discernable from a difference in contrast. The inner layer $\mathrm{Fe}_{2} \mathrm{~B}$ is clearer than the outer layer of $\mathrm{FeB}$. The transition zone is also observed on the all SEM images. It is clear that the obtained boride layers are compact and continuous. The smooth morphology of the 
boride-layer/transition-zone interface is observed in Figure 2.

Figure 3 shows the SEM image (for the EDS analysis) of cross-sections of the boride layer formed on AISI 316 steel at $800{ }^{\circ} \mathrm{C}$ for a treatment time of $3 \mathrm{~h}$. The EDS line scan taken perpendicularly from the surface of the borided sample at $800{ }^{\circ} \mathrm{C}$ for $3 \mathrm{~h}$ showed a qualitative distribution of different elements along the boride layer and the transition zone. It indicates the precipitation of metallic borides inside the boride layer and an accumu-
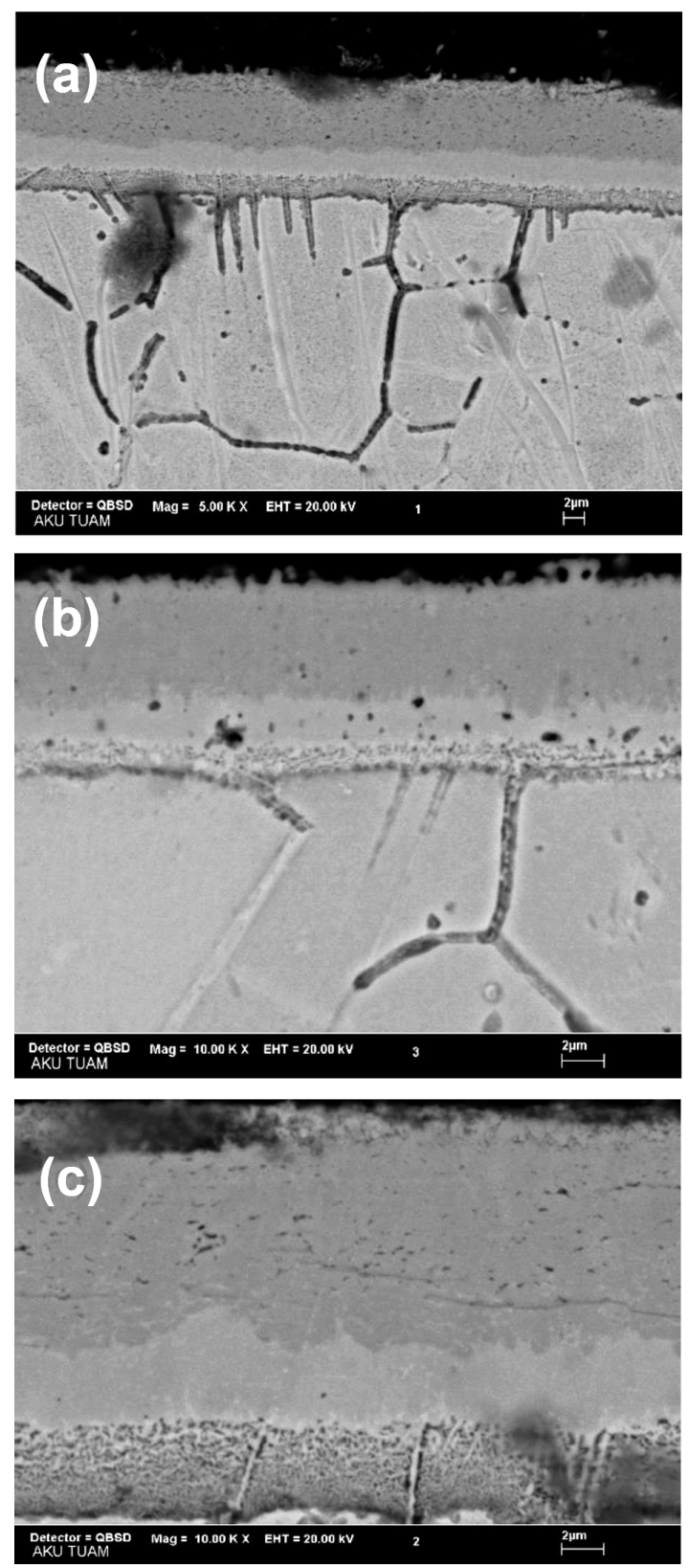

Figure 2: SEM micrographs of the cross-sections of boride layers formed on the AISI 316 steel for different boriding parameters: a) 750 ${ }^{\circ} \mathrm{C}$ for $5 \mathrm{~h}$, b) $750{ }^{\circ} \mathrm{C}$ for $\left.7 \mathrm{~h}, \mathrm{c}\right) 800{ }^{\circ} \mathrm{C}$ for $3 \mathrm{~h}$

Slika 2: SEM-posnetki preseka borirane plasti, nastale na AISI 316 jeklu pri različnih parametrih boriranja: a) $750{ }^{\circ} \mathrm{C}, 5 \mathrm{~h}$, b) $750{ }^{\circ} \mathrm{C}, 7 \mathrm{~h}$, c) $800{ }^{\circ} \mathrm{C}, 3 \mathrm{~h}$ lation of certain elements (such as $\mathrm{Cr}, \mathrm{C}$ and $\mathrm{Mo}$ ) in the transition zone (Figure 3b). In particular, molybdenum has a lower tendency to dissolve in the boride layer and tends to concentrate in the diffusion zone. ${ }^{12}$ In addition, the boride layer thickness was found to increase with the boriding temperature.

\subsection{XRD analysis}

Figure 4 gives the XRD pattern recorded at the surface of the borided AISI 316 steel at $800{ }^{\circ} \mathrm{C}$ for $3 \mathrm{~h}$ of treatment. To confirm the presence of iron and metallic

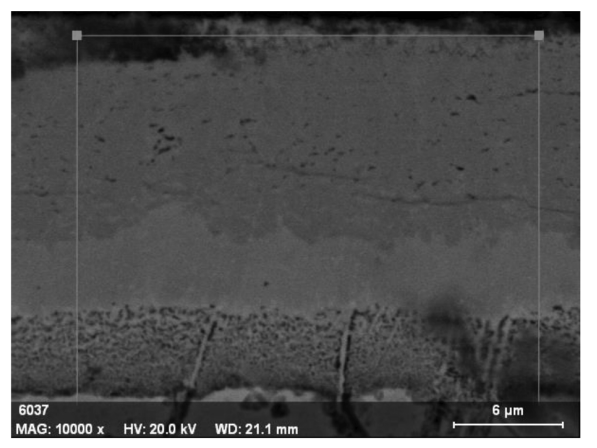

(a)
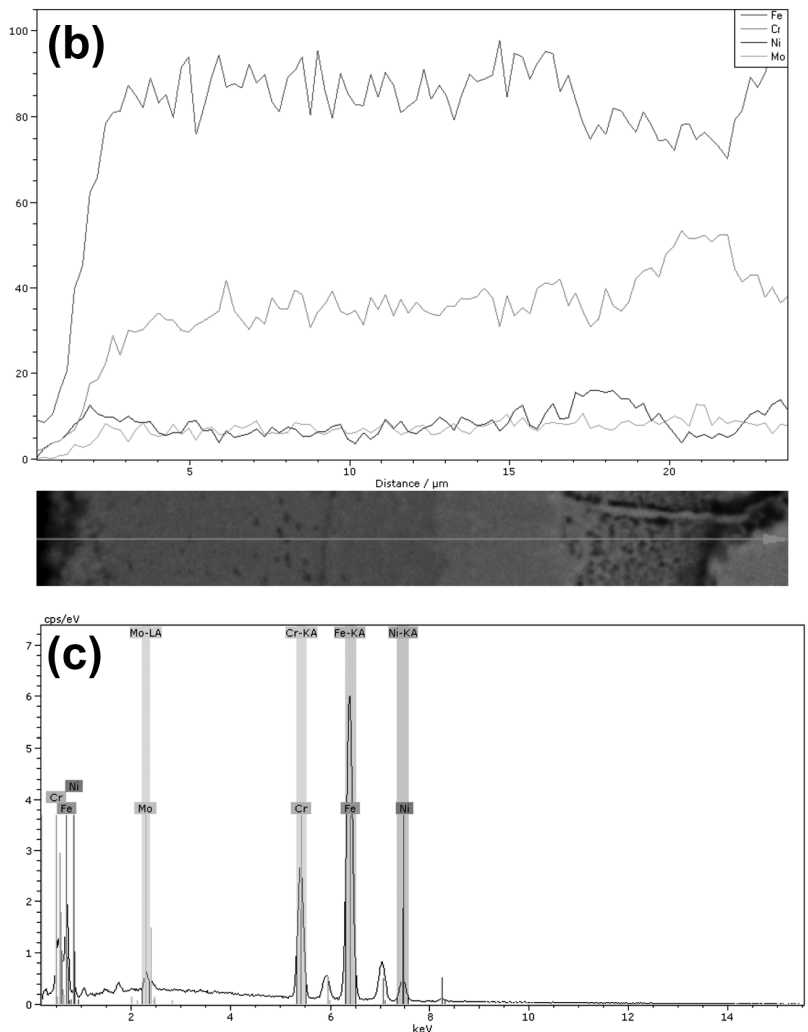

Figure 3: Cross-section of the borided AISI 316 steel at $800{ }^{\circ} \mathrm{C}$ for a treatment time of $3 \mathrm{~h}$ : a) SEM image of the cross-section of a borided sample for EDS analysis, b) EDS line scan across the borided zone, c) EDS spectrum of the selected zone (Figure 3a)

Slika 3: Presek jekla AISI 316, boriranega pri $800{ }^{\circ} \mathrm{C}$, v trajanju $3 \mathrm{~h}$ : a) SEM-posnetek preseka borirane plasti za EDS-analizo, b) EDS-linijska analiza skozi borirano področje, c) EDS-spekter v izbranem področju, ki ga kaže Slika 3a 


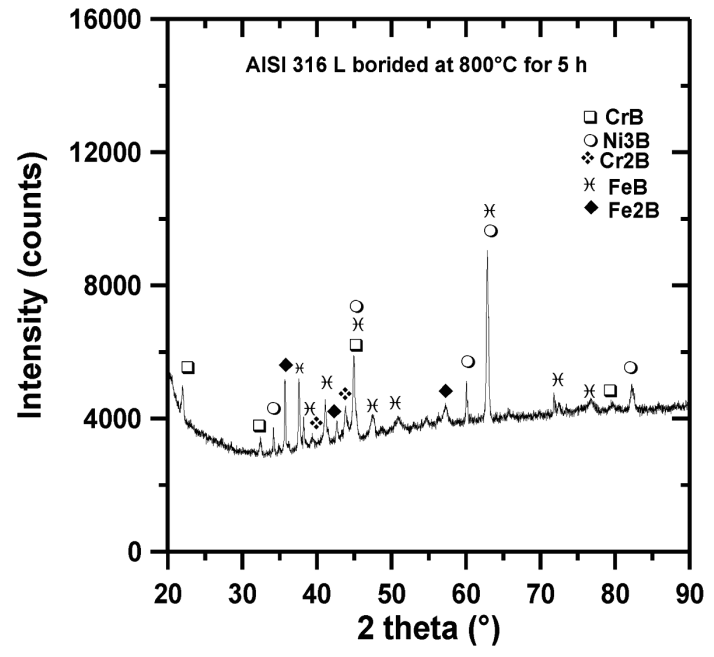

Figure 4: XRD pattern obtained at the surface of borided AISI 316 steel at $800{ }^{\circ} \mathrm{C}$ for $3 \mathrm{~h}$ of treatment

Slika 4: Rentgenogram, dobljen na površini jekla AISI 316, boriranega $3 \mathrm{~h}$ na $800^{\circ} \mathrm{C}$

borides, the corresponding files taken from the JCPDS database ${ }^{13}$ were used.

The iron borides $\left(\mathrm{FeB}\right.$ and $\mathrm{Fe}_{2} \mathrm{~B}$ ) were identified as well as the presence of metallic borides as precipitates within the boride layers such as $\mathrm{CrB}, \mathrm{Cr}_{2} \mathrm{~B}$ and $\mathrm{Ni}_{3} \mathrm{~B}$. In addition, $\mathrm{Cr}$ and $\mathrm{Ni}$ tend to dissolve in the boride layer and form independent metallic borides $\left(\mathrm{CrB}, \mathrm{Cr}_{2} \mathrm{~B}\right.$ and $\left.\mathrm{Ni}_{3} \mathrm{~B}\right)$.

\subsection{Estimation of the boron activation energy}

The growth kinetics of boride layers is controlled by the boron diffusion into the substrate. The boride-layer thickness varies parabolically ${ }^{14-17}$ with the process time given by Equation (1):

$$
u=k^{\prime} \sqrt{t}
$$

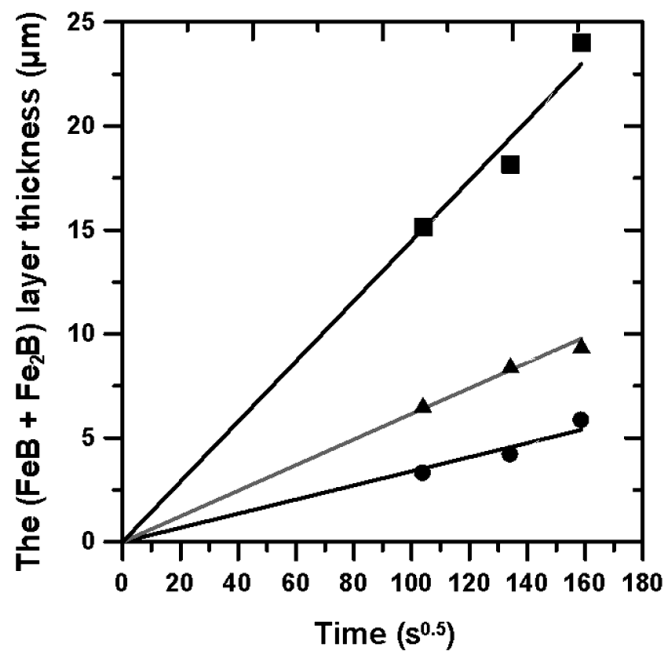

Figure 5: Evolution of the boride layer thickness versus the square root of time for increasing temperatures

Slika 5: Rast debeline borirane plasti pri naraščajoči temperaturi v odvisnosti od kvadratnega korena iz časa where $u$ is the boride-layer thickness (in $\mu \mathrm{m}$ ), $k^{\prime}$ is a parabolic growth constant (in $\mu \mathrm{m} \mathrm{s}^{-1 / 2}$ ) at a given temperature, $D$ is the diffusion coefficient of boron in the boride layer, and $t$ is the boriding time. The time dependence of the boride layer thickness for increasing temperatures is given in Figure 5. It is clear that the boride layer varies linearly with the square root of time, which proves that the growth kinetics of the boride layer is governed by the diffusion phenomenon of boron atoms inside the substrate.

The relationship between the parabolic growth constant $k^{\prime}$ (in $\mu \mathrm{m} \mathrm{s}^{-1 / 2}$ ) and the boriding temperature $T$ in Kelvin, can be expressed using an Arrhenius-type equation as follows:

$$
k^{\prime}=k \sqrt{D_{0} \exp \left(-\frac{Q}{R T}\right)}
$$

where $D_{0}$ is the diffusion coefficient of boron extrapolated at a value of $1 / T=0$. The $Q$ parameter is the activation energy that indicates the amount of energy $\left(\mathrm{kJ} \mathrm{mol}^{-1}\right)$ required for the reaction to occur, and $R$ is the ideal gas constant $\left(R=8.314 \mathrm{~J} \mathrm{~mol}^{-1} \mathrm{~K}^{-1}\right)$. Taking the natural logarithm of Equation (2), we obtain Equation (3):

$$
\ln \left(k^{\prime 2}\right)=\ln \left(k^{2}\right)+\ln \left(D_{0}\right)-\left(\frac{Q}{R T}\right)
$$

The activation energy $Q$ can be easily deduced from the slope of the curve relating $\ln \left(k^{\prime 2}\right)$ to the inverse of the temperature. Figure 6 provides the temperature dependence of the natural logarithm of the square of the parabolic growth constant $k^{\prime 2}$.

The reported values for boron-activation energies $^{4,18-25}$ for borided steels are listed in Table 2 together with the value of the boron-activation energy (250.8 $\mathrm{kJ} \mathrm{mol}^{-1}$ ) estimated from this work. However, these

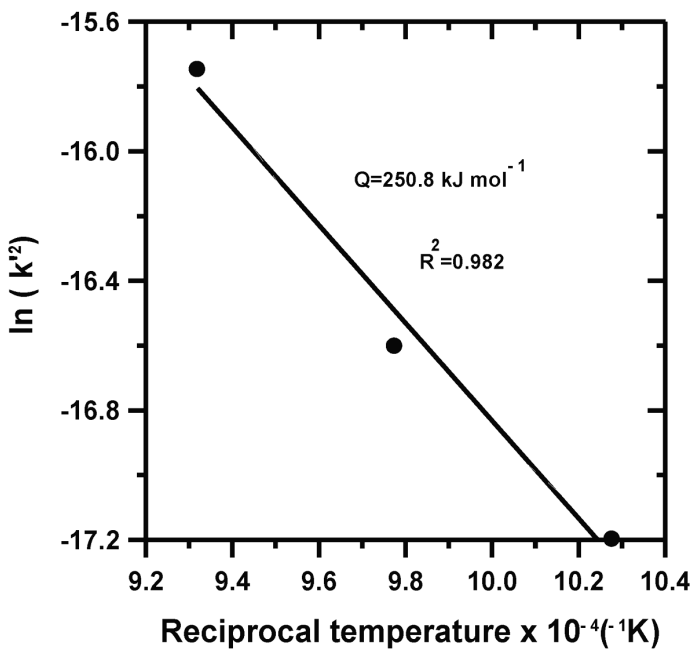

Figure 6: Temperature dependence of the square of the parabolic growth constant

Slika 6: Odvisnost temperature od kvadratnega korena parabolične konstante rasti 
values for the boron-activation energies for different steels depended on various factors such as: the boriding method, the chemical composition of the base steel, the nature of the boriding agent, and the mechanism of boron diffusion. For the paste plasma boriding of AISI 316 steel, the high activation energy shown in Table $\mathbf{2}$ is ascribed to the formation of $\mathrm{FeB}, \mathrm{Fe}_{2} \mathrm{~B}, \mathrm{CrB}, \mathrm{Cr}_{2} \mathrm{~B}$ and $\mathrm{Ni}_{3} \mathrm{~B}$ phases in the boride layer. The obtained value of the boron-activation energy $\left(250.8 \mathrm{~kJ} \mathrm{~mol}^{-1}\right)$ from this work, can also be interpreted as the required barrier to allow boron diffusion inside the steel substrate. Thus, the diffusion phenomenon of boron atoms can occur along the grains boundaries and also in the volume to form the boride layer on the AISI 316 steel.

Table 2: Values of boron-activation energies obtained in the case of borided steels using different methods

Tabela 2: Vrednosti aktivacijske energije bora, dobljene pri boriranju jekel z različnimi metodami

\begin{tabular}{|c|c|c|c|}
\hline Material & $\begin{array}{c}\text { Boriding } \\
\text { method }\end{array}$ & $Q\left(\mathrm{~kJ} \mathrm{~mol}^{-1}\right)$ & References \\
\hline AISI 304 & Salt Bath & 253.35 & 18 \\
\hline AISI H13 & Salt bath & 244.37 & 18 \\
\hline AISI 4140 & Paste & 168.5 & 19 \\
\hline AISI H13 & Powder & 186.2 & 20 \\
\hline AISI 1040 & Powder & 168 & 21 \\
\hline AISI440C & Powder & 340.4 & 22 \\
\hline AISI 316 & Powder & 199 & 23 \\
\hline AISI 51100 & Plasma & 106 & 24 \\
\hline AISI 304 & $\begin{array}{c}\text { Plasma Paste } \\
\text { Boriding }\end{array}$ & 123 & 4 \\
\hline AISI8620 & $\begin{array}{c}\text { Plasma Paste } \\
\text { Boriding }\end{array}$ & $124.7-138.5$ & 25 \\
\hline AISI 316 & $\begin{array}{c}\text { Plasma Paste } \\
\text { boriding }\end{array}$ & 250.8 & This work \\
\hline
\end{tabular}

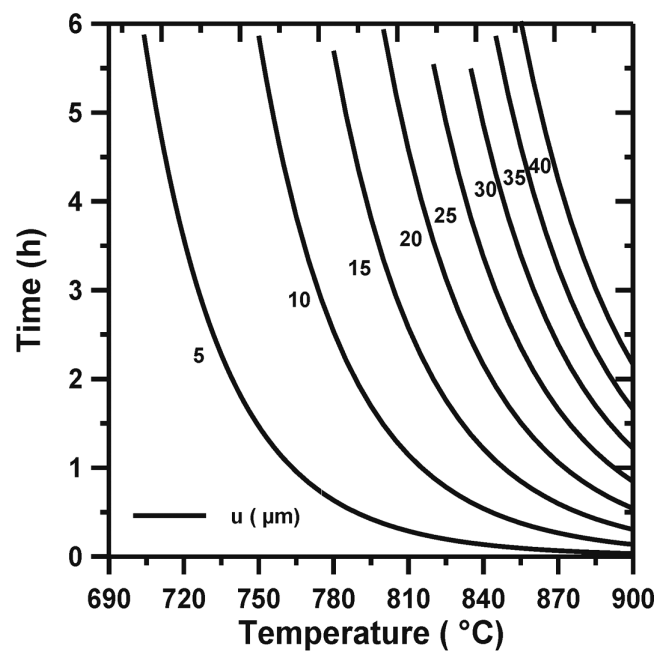

Figure 7: Iso-thickness diagram describing the evolution of the boride-layer thickness as a function of the boriding parameters (time and temperature)

Slika 7: Diagram enakih debelin opisuje razvoj debeline borirane plasti v odvisnosti od parametrov boriranja (čas in temperatura)

\subsection{Prediction of the boride-layer thickness with a re- gression model}

A full factorial design with two factors at three levels ${ }^{26}$ was used to predict the boride-layer thickness as a function of the boriding parameters (time and temperature).

Using this approach, Equation (4) was obtained as follows:

$$
\begin{aligned}
& u=761.50-2.0856 T-11.763 t+ \\
& +0.015825 t T+0.001435 T^{2}+0.108333 t^{2}
\end{aligned}
$$

where $t$ is the boriding time (h) and $T$ is the temperature in degree Celsius.

Table 3: Comparison between the experimental values of the boridelayer thicknesses and those given by Equation (1) and the regression model (Equation 4) in the temperature range $700-800{ }^{\circ} \mathrm{C}$

Tabela 3: Primerjava eksperimentalnih vrednosti debeline borirane plasti z vrednostmi iz enačbe (1) in iz regresijskega modela (enačba

\begin{tabular}{|c|c|c|c|c|}
\hline $\begin{array}{c}T \\
\left({ }^{\circ} \mathrm{C}\right)\end{array}$ & $\begin{array}{c}\text { Time } \\
\text { (h) }\end{array}$ & $\begin{array}{c}\text { Predicted } \\
\left(\mathrm{FeB}+\mathrm{Fe}_{2} \mathrm{~B}\right) \\
\text { Layer thickness } \\
(\mu \mathrm{m}) \\
\text { Equation }(1)\end{array}$ & $\begin{array}{c}\text { Predicted } \\
(\text { FeB+Fe } \mathrm{B}) \\
\text { Layer thickness } \\
(\mu \mathrm{m}) \\
\text { Equation }(4)\end{array}$ & $\begin{array}{c}\text { Experimental } \\
\left(\mathrm{FeB}+\mathrm{Fe}_{2} \mathrm{~B}\right) \text { layer } \\
\text { thickness } \\
(\mu \mathrm{m})\end{array}$ \\
\hline 700 & 3 & 3.59 & 3.34 & 3.30 \\
\hline 700 & 5 & 3.92 & 4.32 & 4.20 \\
\hline 700 & 7 & 5.11 & 5.11 & 5.84 \\
\hline 750 & 3 & 5.72 & 7.15 & 6.60 \\
\hline 750 & 5 & 7.63 & 9.23 & 8.50 \\
\hline 750 & 7 & 10.40 & 10.92 & 9.45 \\
\hline 800 & 3 & 15.02 & 14.20 & 15.13 \\
\hline 800 & 5 & 18.51 & 18.34 & 18.16 \\
\hline 800 & 7 & 22.86 & 21.70 & 24.00 \\
\hline
\end{tabular}
4), v temperaturnem območju $700-800{ }^{\circ} \mathrm{C}$

Table 3 compares between the experimental values of the boride layers' thicknesses and the predicted values using Equations (1) and (4) in the temperature range 700 ${ }^{\circ} \mathrm{C}-800{ }^{\circ} \mathrm{C}$. A good agreement was observed between the simulated values of the boride layers' thicknesses and those obtained experimentally. Equation (1) can be used to plot the iso-thickness diagram shown in Figure 7. The iso-thickness diagram can serve as a simple tool to select the optimum value of the boride-layer thickness for a practical use of the plasma paste borided AISI 316 steel in industry. As a rule, thin layers (e.g., $15 \mu \mathrm{m}-20 \mu \mathrm{m}$ ) are used to protect against adhesive wear (such as chipless shaping and metal stamping dies and tools), whereas thick layers are recommended to combat abrasive wear (extrusion tooling for plastics with abrasive fillers and pressing tools for the ceramics industry). In the case of low-carbon steels and low-alloy steels, the optimum boride-layer thicknesses are between $50 \mu \mathrm{m}$ and $250 \mu \mathrm{m}$.

\section{CONCLUSIONS}

In this work AISI 316 steel was plasma paste borided in a gas mixture of $70 \% \mathrm{H}_{2}-30 \%$ Ar using a mixture of $30 \% \mathrm{SiC}+70 \% \mathrm{~B}_{2} \mathrm{O}_{3}$. The boride-layer/transition- 
zone interface had a smooth morphology with a boride layer thickness ranging from $3.3 \mu \mathrm{m}$ to $24 \mu \mathrm{m}$.

The boride layer formed on the surface of the AISI 316 was composed of $\mathrm{FeB}, \mathrm{Fe}_{2} \mathrm{~B}, \mathrm{CrB}, \mathrm{Cr}_{2} \mathrm{~B}$ and $\mathrm{Ni}_{3} \mathrm{~B}$ phases. This result was confirmed by XRD analysis and a transition zone was also visible beneath the boride layer. The boron-activation energy for the AISI 316 steel was estimated to be $250.8 \mathrm{~kJ} \mathrm{~mol}^{-1}$. This value was interpreted as the required quantity of energy to stimulate the boron diffusion in the preferential direction $\left(\begin{array}{lll}0 & 0 & 1\end{array}\right)$. This value of the boron-activation energy was comparable to values found in the literature.

In addition, an iso-thickness diagram describing the evolution of the boride-layer thickness as a function of the boriding parameters was proposed. It can serve as a simple tool to select the optimum boride layer thickness according to the practical use of borided AISI 316 steel.

\section{REFERENCES}

${ }^{1}$ A. K. Sinha, Boriding (Boronizing) of steels, ASM Handbook, vol. 4, Heat treating, ASM International, 1991, 437-447

${ }^{2}$ S. Ulker, I. Gunes, S. Taktak, Investigation of tribological behaviour of plasma paste boronized of AISI 8620, 52100 and 440c steels, Indian Journal of Engineering and Materials Sciences, 18 (2011) 5, 370-376

${ }^{3}$ I. Uslu, H. Comert, M. Ipek, O. Ozdemir, C. Bindal, Evaluation of borides formed on AISI P20 steel, Materials and Design, 28 (2007) 1, 55-61, doi:10.1016/j.matdes.2005.06.013

${ }^{4}$ J. H. Yoon, Y. K. Jee, S. Y. Lee, Plasma paste boronizing treatment of the stainless steel AISI 304, Surface and Coatings Technology, 112 (1999) 1-3, 71-75, doi:10.1016/S0257-8972(98)00743-9

${ }^{5}$ I. Gunes, S. Ulker, S. Taktak, Plasma paste boronizing of AISI 8620, 52100 and $440 \mathrm{C}$ steels, Materials and Design, 32 (2011) 4, 2380-2386, doi:10.1016/j.matdes.2010.11.031

${ }^{6}$ C. Bindal, A. H. Ucisik, Characterization of boriding of $0.3 \% \mathrm{C}$, $0.02 \%$ P plain carbon steel, Vacuum, 82 (2008) 1, 90-94, doi:10.1016/ j.vacuum.2007.04.039

${ }^{7}$ M. Keddam, M. Kulka, N. Makuch, A. Pertek, L. Małdziński, A kinetic model for estimating the boron activation energies in the FeB and $\mathrm{Fe}_{2} \mathrm{~B}$ layers during the gas-boriding of Armco iron: Effect of boride incubation times, Applied Surface Science, 298 (2014), 155-163, doi:10.1016/j.apsusc.2014.01.151

${ }^{8} \mathrm{~S}$. Sahin, C. Meric, Investigation of the effect of boronizing on cast irons, Materials Research Bulletin, 37 (2002) 5, 971-979, doi:10.1016/S0025-5408(02)00697-9

${ }^{9}$ I. Campos-Silva, M. Ortiz-Dominguez, M. Keddam, N. LopezPerrusquia, A. Carmona-Vargas, M. Elias-Espinosa, Kinetics of the formation of $\mathrm{Fe}_{2} \mathrm{~B}$ layers in gray cast iron: Effects of boron concentration and boride incubation time, Applied Surface Science, 255 (2009) 22, 9290-9295, doi:10.1016/j.apsusc.2009.07.029

${ }^{10}$ J. G. Buijnsters, P. Shankar, P. Gopalakrishnan, W. J. P. Van Enckevort, J. J. Schermer, S. S. Ramakrishnan, J. J. Ter Meulen, Diffusion-modified boride interlayers for chemical vapour deposition of low-residual-stress diamond films on steel substrates, Thin Solid Films, 426 (2003) 1-2, 85-93, doi:10.1016/S0040-6090(03)00013-0
${ }^{11}$ K. A. Khor, L. G. Yu, G. Sundararajan, Formation of hard tungsten boride layer by spark plasma sintering boriding, Thin Solid Films, 478 (2005) 1-2, 232-237, doi:10.1016/j.tsf.2004.07.004

${ }^{12}$ I. S. Dukarevich, M. V. Mozharov, A. S. Shigarev, Redistribution of elements in boride coatings, Metal Science and Heat Treatment, 15 (1973) 2, 160-162, doi:10.1007/BF00679753

${ }^{13}$ JCPDS- International Centre for Diffraction Data, PCPDF WIN, Version 202, 1999

${ }^{14}$ N. Ucar, O. B. Aytar, A. Calik, Temperature behaviour of the boride layer of a low-carbon microalloyed steel, Mater. Tehnol., 46 (2012) 6, 621-625

${ }^{15}$ X. Tian, Y. L. Yang, S. J. Sun, J. An, Y. Lu, Z. G. Wang, Tensile Properties of Boronized N80 Steel Tube Cooled by Different Methods, Journal of Materials Engineering and Performance, 18 (2009) 2, 162-167, doi:10.1007/s11665-008-9270-0

${ }^{16} \mathrm{~L}$. Xu, X. Wu, H. Wang, Influence of Surface Nano-structured Treatment on Pack Boriding of H13 Steel, J. Mater. Sci. Technol., 23 (2007) 4, 525-528

${ }^{17}$ B. Bouarour, M. Keddam, O. Allaoui, O. Azouani, Boriding kinetics of C35 steel: Estimation of boron activation energy and the mass gain, Metallurgical Research and Technology, 111 (2014) 2, 67-73, doi:10.1051/metal/2014015

${ }^{18} \mathrm{~S}$. Taktak, A study on the diffusion kinetics of borides on boronized Cr-based steels, Journal of Materials Science, 41 (2006) 22, 7590-7596, doi:10.1007/s10853-006-0847-4

${ }^{19}$ Z. Nait Abdellah, M. Keddam, A. Elias, Evaluation of the effective diffusion coefficient of boron in the $\mathrm{Fe}_{2} \mathrm{~B}$ phase in the presence of chemical stresses, International Journal of Materials Research, 104 (2013) 3, 260-265, doi:10.3139/146.110862

${ }^{20} \mathrm{~K}$. Genel, Boriding kinetics of H13 steel, Vacuum, 80 (2006) 5 , 451-457, doi:10.1016/j.vacuum.2005.07.013

${ }^{21}$ I. Uslu, H. Comert, M. Ipek, F. G. Celebi, O. Ozdemir, C. Bindal, A comparison of borides formed on AISI 1040 and AISI P20 steels, Materials and Design, 28 (2007) 28, 1819-1826, doi:10.1016/ j.matdes.2006.04.019

${ }^{22}$ Y. Kayali, I. Günes, S. Ulu, Diffusion kinetics of borided AISI 52100 and AISI 440C steels, Vacuum, 86 (2012) 10, 1428-1434, doi:10.1016/j.vacuum.2012.03.030

${ }^{23}$ O. Ozdemir, M. A. Omar, M. Usta, S. Zeytin, C. Bindal, A. H. Ucisik, An investigation on boriding kinetics of AISI 316 stainless steel, Vacuum, 83 (2008) 1, 175-179, doi:10.1016/j.vacuum.2008.03.026

${ }^{24}$ M. Ipek, G. Celebi Efe, I. Ozbek, S. Zeytin, C. Bindal, Investigation of boronizing kinetics of AISI 51100 steel, Journal of Materials Engineering and Performance, 21 (2012) 5, 733-738, doi:10.1007/ s11665-012-0192-5

${ }^{25}$ I. Gunes, S. Taktak, C. Bindal, Y. Yalcin, S. Ulker, Y. Kayali, Investigation of diffusion kinetics of plasma paste borided AISI 8620 steel using a mixture of $\mathrm{B}_{2} \mathrm{O}_{3}$ paste and $\mathrm{B}_{4} \mathrm{C} / \mathrm{SiC}$, Sadhana - Academy Proceedings in Engineering Sciences, 38 (2013) 3, 513-526, doi:10.1007/s12046-013-0136-2

${ }^{26}$ J. Goupy, Plans d'expériences pour surfaces de réponses, Edition Dunod, Paris 1999, 1-409 